\title{
Physiological behaviour of Blepharocalyx salicifolius and Casearia decandra seeds on the tolerance to dehydration ${ }^{1}$
}

\author{
Suelen Santos Rego*2, Antonio Carlos Nogueira ${ }^{3}$, Antonio Carlos de Souza Medeiros ${ }^{4}$, \\ Carmen Lúcia de Oliveira Petkowicz $z^{5}$ Álvaro Figueredo dos Santos ${ }^{6}$
}

\begin{abstract}
The present work aimed to develop studies on the tolerance to dehydration of Blepharocalyx salicifolius and Casearia decandra seeds. In order to verify the effect of drying on the seeds, they were placed in desiccators containing a saline solution saturated with potassium acetate $(23.5 \% \mathrm{RH})$ at temperature of $15{ }^{\circ} \mathrm{C}$. After obtaining the desired moisture contents, the seeds were submitted to the germination, vigor, tetrazolium and electrical conductivity tests. It can be concluded that under slow drying conditions, the seeds of B. salicifolius and C. decandra were sensitive to moisture reduction of $29 \%$ to $25 \%$, and lost viability at around $14 \%$ and $8 \%$ of moisture content, respectively. The physiological changes occurring during seed drying showed there was a decrease in viability and vigor and an increase in electrical conductivity values starting at $25 \%$ seed moisture content.
\end{abstract}

Index terms: seed drying, recalcitrant, desiccation tolerance.

\section{Comportamento fisiológico das sementes de Blepharocalyx salicifolius e Casearia decandra em relação à tolerância a desidratação}

\begin{abstract}
RESUMO - Este trabalho teve como objetivo desenvolver estudos sobre a tolerância a desidratação das sementes de Blepharocalyx salicifolius e Casearia decandra. Para verificar os efeitos da secagem nas sementes, estas foram colocadas em dessecadores contendo solução salina saturada de acetato de potássio $\left(23,5 \%\right.$ UR) na temperatura de $15^{\circ} \mathrm{C}$. Após a obtenção dos graus de umidade desejados, as sementes foram submetidas aos testes de germinação, de vigor, de tetrazólio e de condutividade elétrica. Diante dos resultados obtidos pode-se concluir que em condições de secagem lenta, as sementes de $B$. salicifolius e $C$. decandra foram sensíveis à redução de umidade entre $29 \%$ e $25 \%$ e perderam a viabilidade em torno de $14 \%$ e $8 \%$ de umidade, respectivamente. Quanto às alterações fisiológicas ocorridas durante a secagem das sementes, observou-se diminuição da viabilidade e do vigor e aumento nos valores de condutividade elétrica a partir de $25 \%$ de umidade.
\end{abstract}

Termos para indexação: secagem de sementes, recalcitrante, tolerância à dessecação.

\section{Introduction}

Desiccation tolerance is a mechanism that allows organisms to go through a rigorous process of drying and maintain their physiological activities when rehydrated (Alpert, 2000).

The physiological condition of the seed in relation to desiccation tolerance and storage was initially studied by Roberts (1973), which classified seeds into orthodox (tolerant) and recalcitrant (non-tolerant). Later, Ellis et al. (1990) introduced the class of intermediates, whose behavior during drying and storage at times presents features similar to

${ }^{1}$ Submitted on 10/30/2012. Accepted for publication on 06/11/2013.

${ }^{2}$ Departamento de Engenharia Florestal, UFPR, 80210-170 - Curitiba, PR, Brasil.

${ }^{3}$ Departamento de Ciência Florestal, UFPR, 80210-170 - Curitiba, PR, Brasil.

${ }^{4}$ Embrapa Florestas, Caixa Postal 319, 83411-000 - Colombo, PR, Brasil orthodox seeds, and at times similar to recalcitrant seeds.

According to this classification, seeds that can be dried to very low amounts of water, between $5 \%$ and $7 \%$, without losing viability, are regarded as orthodox. The longevity of seeds in this group is, depending on the species, increased progressively with the reduction of their moisture content and storage at low temperatures. Seeds called recalcitrant are those that possess a high degree of moisture when breaking off from the parent plant at the end of maturation and that die when their degree of moisture is reduced to values below that of their critical moisture level (15 to $50 \%)$. In addition to this fact, recalcitrant seeds do not support storage under freezing temperatures (Roberts, 1973).

\footnotetext{
${ }^{5}$ Departamento de Bioquímica, UFPR, 81531980 - Curitiba, PR, Brasil. ${ }^{6}$ Embrapa Florestas, Caixa Postal 319, 83411-000 - Colombo, PR, Brasil. *Corresponding author<suelen_srego@yahoo.com.br>
} 
Intermediate seeds survive moderately to dryness until they reach around $12 \%$ moisture. However, moisture values below this value, as well as storage in freezing temperatures are harmful to their longevity (Ellis et al., 1990).

Farrant et al. (1988) suggested that there are different types of recalcitrant seeds: minimally, moderately and highly recalcitrant. Other authors also observed that intolerance to dehydration is not absolute, because if seeds of different species are dehydrated using the same procedure, they will not present identical drops of viability levels due to the different degrees of tolerance to water loss (Berjak and Pammenter, 2000).

According to Pammenter et al. (2000) there are indications that the minimum moisture content in the seed that can be harmful and lead to viability loss in recalcitrant seeds is highly variable within and among species. Thus, desiccation sensitivity seems to vary from extremely to moderately sensitive, when the seeds' rate of drying can be one of the factors contributing to the variation in sensitivity observed.

Thus, in studying the physiological behavior of seeds in relation to drying, factors such as the drying speed and environmental conditions in which the seeds were produced should be taken into consideration. Studies by Dussert et al. (2000) showed that Coffea sp. seeds dispersed in a longer drought period were more tolerant than those who were dispersed in shorter drought periods, and the works of Daws et al. (2005) showed that seeds obtained from different sources obtained different tolerance levels according to the temperature at which they were produced.

Blepharocalyx salicifolius belongs to the Myrtaceae family and is popularly known as myrtle. It is a small to large tree (4-30 m) (Marchiori and Sobral, 1997) that occurs in Deciduous Forest, Semi-deciduous Forest, Rain Forest, Araucaria Forest, Restinga, Cerrado and in Fields. It can be used for planting along the banks of rivers, because it occurs naturally in these environments and attract seed disperser birds (Carvalho, 2006).

Casearia decandra, popularly known as guaçatonga, belongs to the Salicaceae family. It is an arboreal species of small to large size (4 to $18 \mathrm{~m}$ tall), which can be found in the Rain Forest and Araucaria Forest, Deciduous Forest, Cerrado, pioneer formations with marine influence (Restinga) and Alluvial Forest. It produces a large amount of flowers for the production of honey of excellent quality, and the fruits are edible and highly sought after by birds (Klein and Sleumer, 1984). According to Pio Correa (1984) the species has a medicinal use and currently there are studies on their pharmacological properties (Thadeo et al., 2009).

Information about the physiological behavior of the seeds of B. salicifolius and C. decandra are scarce, but there are some indications in the literature of recalcitrant species. They have fleshy fruit and their dispersion season occurs from December to March, a period of relatively high rainfall and temperatures, favoring germination right after abscission from the parent plant; the species occurs in Tropical Forests; its seeds have a thin tegument, not presenting dormancy and germinating quickly. Some authors also suggest the low longevity of its seeds (Lorenzi, 1998; Carvalho, 2006; Rego et al., 2010).

Due to the importance of knowing the physiological behavior of seeds in relation to drying for future storage works and also to the lack of information on the dehydration tolerance of these species, the aim of this study was to develop an initial study on the physiological behavior of these species in relation to dryness.

\section{Materials and Methods}

The fruits of B. salicifolius were collected from 12 parents in 2009 in a fragment of Araucaria Forest located in Araucaria - PR, and those of C. decandra were collected from 12 parents in 2009 in a fragment of Araucaria Forest in the urban region of Curitiba - PR.

In the municipalities where the sampling of fruits was carried out, the weather according to the Koeppen classification is mesothermal humid subtropical $(\mathrm{Cfb})$, with cool summers, winters with severe and frequent frosts, with no dry season. The annual average maximum temperature is $23-24{ }^{\circ} \mathrm{C}$, minimum being $15-16^{\circ} \mathrm{C}$ and average $16-18{ }^{\circ} \mathrm{C}$, and the average annual rainfall is $1400-1600 \mathrm{~mm}$ /year (IAPAR, 2011).

The fruits were previously separated with respect to their maturity, based on the epicarp color. For B. salicifolius, were selected fruits with red coloring, and for $C$. decandra, those of yellow coloring (characteristics observed in the dispersed fruits). These were manually processed by washing in running water, and seeds were dried in laboratory conditions (temperature of $18-20{ }^{\circ} \mathrm{C}$ and $75 \% \mathrm{RH}$ ) for 24 hours in order to remove excess processing water.

Assessment of the physiological behavior of the seeds in relation to desiccation tolerance: the fresh seeds were placed in petri dishes on a porcelain plate in $6 \mathrm{~L}$ desiccators containing $200 \mathrm{~g}$ of potassium acetate and $27 \mathrm{~mL}$ of distilled water, thus obtaining a saturated saline solution. The solution was prepared according to solubility, following the procedure described in the Merck (1989) manual and by Medeiros (2006), which, after stabilization, promotes a relative humidity (RH) 23.5\% (Sun, 2002; Rockland, 1960; Winston and Bates, 1960; Vertucci and Ross, 1993). The desiccators were kept in an environment with a controlled temperature of $15^{\circ} \mathrm{C}$ and relative humidity of $40 \% \pm 2 \%$. A 
thermo-hygrometer was placed inside the desiccators to ensure that relative humidity was maintained during the experiments.

After stabilization of the $\mathrm{RH}$ in desiccators, a sample of $20 \mathrm{~g}$ of seeds was weighed daily for checking the water loss. When the seeds reached the desired percentages of water: $37 \%$ (freshly harvested seed), 33\%, 29\%, 25\%, 18\% and $14 \%$ for B. salicifolius and $54 \%$ (freshly harvested seed) $49 \%, 38 \%, 25 \%, 21 \%, 14 \%$ and $8 \%$ for $C$ decandra, they were removed from the desiccators and were performed tests of germination, vigor, moisture content, tetrazolium and electrical conductivity.

Moisture content of the seeds (wet basis): was obtained by the forced ventilated oven method at $105^{\circ} \mathrm{C} \pm 3{ }^{\circ} \mathrm{C}$ for 24 hours, according to the Rules for Seed Testing (Brasil, 2009), using three replicates of 200 seeds.

Rehydration treatment: for seeds that were dried, a slow rehydration treatment was performed to prevent damage to cell membranes due to rapid hydration. The seeds were placed on a stainless steel screen in plastic gerboxes. Within these boxes, below the screen, were placed $40 \mathrm{~mL}$ of distilled water. The test was conducted in a laboratory room (uncontrolled environment) for 24 hours.

Germination test: five replications of 30 seeds were used. Seeds of B. salicifolius were placed in plastic boxes (gerbox) previously sterilized with $70 \%$ ethanol containing $20 \mathrm{~g}$ of vermiculite and $60 \mathrm{~mL}$ of distilled water. Seeds of $C$. decandra were placed on rolled paper moistened with distilled water and placed in plastic bags placed in a Biomatic incubator at $25^{\circ} \mathrm{C}$. The evaluations were performed daily until the seeds stopped germinating. The seeds were considered germinated once they presented radicle with at least $2 \mathrm{~mm}$. The germination speed index (GSI) (Maguire, 1962) and germination percentage were calculated.

Conductivity test: for seeds of B. salicifolius four replicates of 25 seeds were used, soaked in $75 \mathrm{~mL}$ of distilled water for 24 hours; and for $C$. decandra, there were four replications of 50 seeds, soaked in $50 \mathrm{~mL}$ of distilled water for 6 hours at $25^{\circ} \mathrm{C}$, according to the methodology standardized in preliminary tests. After these periods, the electrical conductivity was read on the soaking solution using a conductivity meter and the data were expressed in $\mu \mathrm{S} . \mathrm{cm}^{-1} \cdot \mathrm{g}^{-1}$.

Tetrazolium test: four replicates of 50 seeds were presoaked for 24 hours, according to methodology standardized in preliminary tests, under paper towel moistened with distilled water and kept in an incubator at $25{ }^{\circ} \mathrm{C}$. After this period, the embryos were extracted from the seeds, and those of $B$. salicifolius were cut in half and placed in the tetrazolium solution at $30{ }^{\circ} \mathrm{C}$ in the dark. For B. salicifolius a concentration of $0.5 \%$ tetrazolium was used $(2,3,5$ triphenyltetrazolium chloride) for 5 hours, and for $C$. decandra, a concentration of $0.075 \%$ was used for 3 hours. After these periods, the seeds were washed to remove the solution still present in the tissues, and the assessments were carried out based on the coloring of the embryo according to the methodology standardized in preliminary tests.

Statistical analysis: the experiments were conducted according to the completely randomized design and evaluated through polynomial regression analysis. When polynomial regressions were adjusted, the equation of higher determination coefficient was adopted. Analyses were performed using the statistical software Assistat ${ }^{\circledR}$, and graphics were made on Excel.

\section{Results and Discussion}

Seeds of B. salicifolius at the moment of collection had $37 \%$ moisture content, and when placed under relative humidity of $23.5 \%$ and a temperature of $15{ }^{\circ} \mathrm{C}$, the moisture content decreased gradually, reaching $14 \%$ after 51 days in the saline solution. Now the $C$. decandra seeds had $54 \%$ moisture at the time of collection and when subjected to the conditions described, the moisture content decreased gradually until reaching $8 \%$ after 39 days under saline solution (Figure 1).
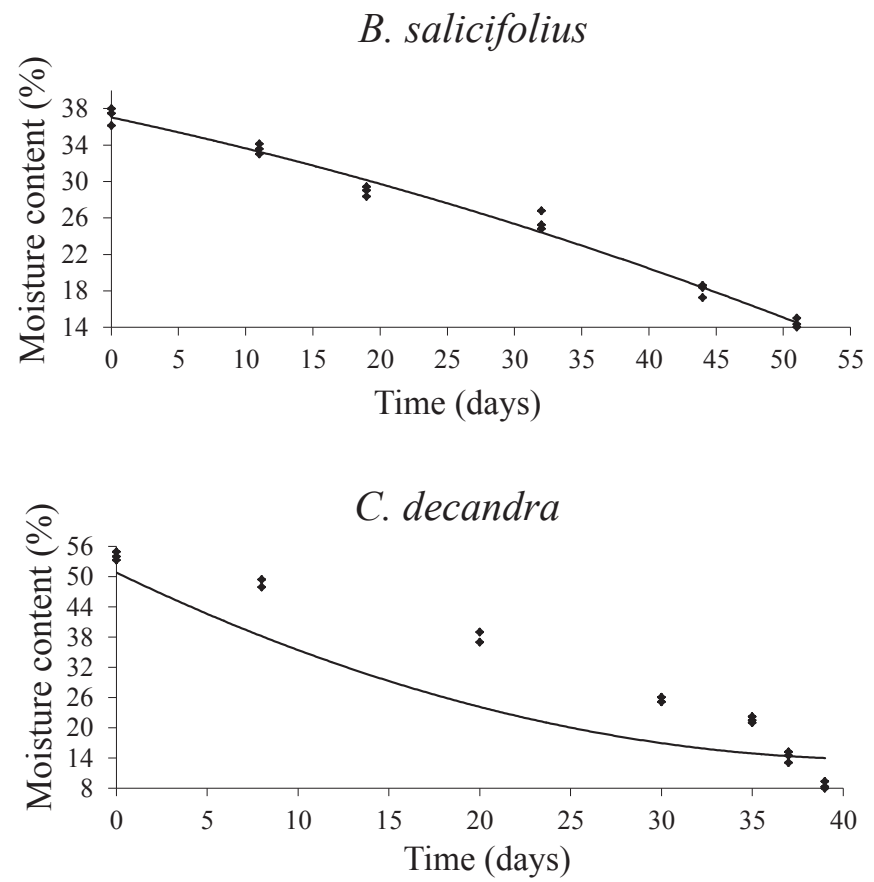

Figure 1. Drying curve of Blepharocalyx salicifolius and Casearia decandra seeds in saline solution saturated with potassium acetate $(23.5 \% \mathrm{RH})$. 
The incubation period of seeds in the saline solution is in accordance with the period found for other species. For the Sebastiania commersoniana and Miconia cabucu seeds maintained in a potassium acetate solution, the moisture content equilibrium was reached at 30 days (Abreu and Medeiros, 2005ab). Caddah et al. (2005) found that, for Talauma ovata seeds kept in the same saline solution, the equilibrium content was established at 56 days.

The drying condition used in this study allowed for slow drying (39 and 51 days of drying for $C$. decandra and $B$. salicifolius, respectively). Carvalho et al. (2008) working with species of the genus Nectandra and Ocotea also used slow drying to evaluate the behavior of these species in relation to drying. The drying time for these species varied from 50 to 75 days.

Pammenter et al. (2000) highlighted two types of damage that occur in recalcitrant seeds when submitted to slow drying: damage related to macromolecules and damage resulting from maintaining the seeds in intermediate levels of water, leading to oxidative stress as a consequence of a deregulated metabolism, which may have happened to the seeds in this study, since the seeds remained for several days with an elevated moisture content. Some authors found that the drying rate can influence the tolerance to desiccation. For the recalcitrant seeds Avicenia marina (Farrant et al., 1986) and Ekebergia capensis (Pammenter et al., 2000), it was verified that rapid drying allowed for a higher level of tolerance to drying. In further works of desiccation tolerance in seeds of $B$. salicifolius and $C$. decandra other (rapid) drying methods must be tested to verify a possible higher level of tolerance to drying.

For seeds of $B$. salicifolius the following moisture contents were obtained: $37 \%$ (freshly harvested seed) $33 \%$, $29 \%, 25 \%, 18 \%$ and $14 \%$; and for C. decandra: $54 \%$ (freshly harvested seed) $49 \%, 38 \%, 25 \%, 21 \%, 14 \%$ and $8 \%$.

The germination percentage of $B$. salicifolius seeds with $37 \%$ moisture content was $93 \%$, and with seed drying the germination percentage decreased to $85 \%$ at $29 \%$ moisture content, drastically decreasing to $60 \%$ at $25 \%$ moisture content, and at $14 \%$ seed moisture, germination was zero (Figure 2).

The seeds of $C$. decandra showed $54 \%$ of initial moisture and an average germination of $91 \%$. With seed drying, germination remained high up to $38 \%$ moisture content, with a decrease to $70 \%$ germination at $25 \%$ moisture content, $56 \%$ at $21 \%$ moisture and $12 \%$ at $14 \%$ moisture, and with $8 \%$ moisture content, germination was zero (Figure 2).

Studying various species of Eugenia sp. Barbedo and Delgado (2007) found sensitivity levels to recalcitrance between species. The seeds most sensitive to desiccation were Eugenia pyriformis, which presented an initial loss of viability with the moisture content being higher and near $65 \%$.
The seeds of E. uniflora, E. brasiliensis and E. involucrata stood at an intermediate position regarding sensitivity to desiccation, with an initial loss of viability in a moisture content of approximately 45-50\%. E. umbelliflora and E. cerasiflora initiated the loss of viability when the moisture content was around $45 \%$. The moisture content lethal to the species of Eugenia was $15 \%$ to $20 \%$, similar to that found for B. salicifolius, a species of the same botanical family.
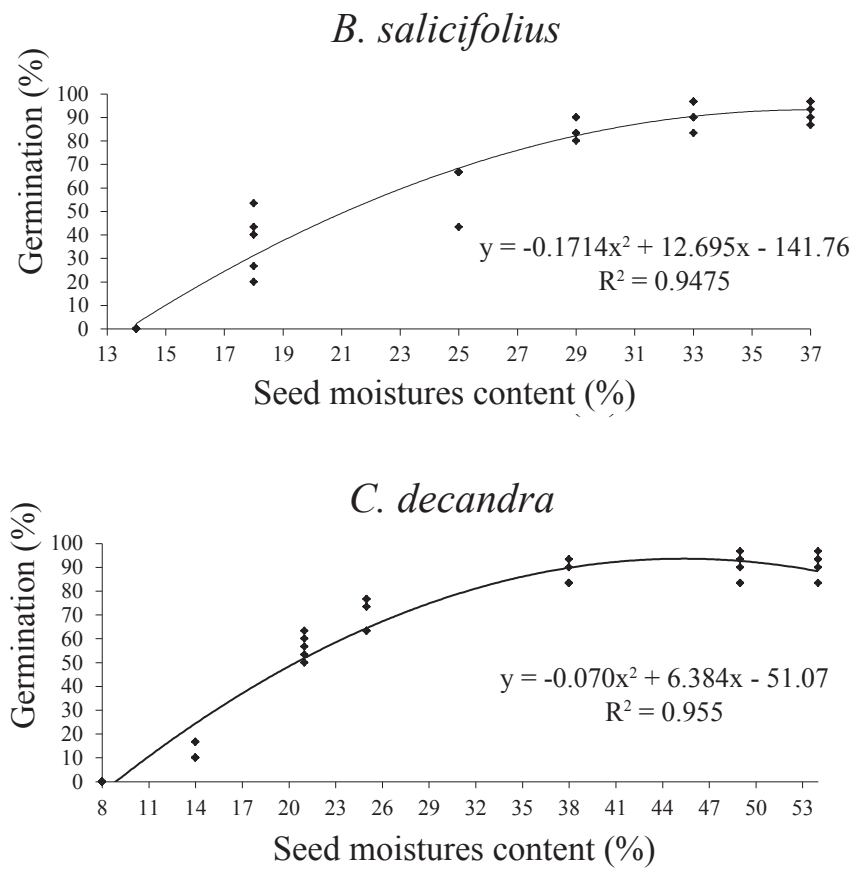

Figure 2. Germination percentage of Blepharocalyx salicifolius and Casearia decandra seeds with different moisture contents.

Based on these results, it can be seen that under conditions of slow drying, the seeds of $B$. salicifolius and $C$. decandra were sensitive to moisture reduction between $29 \%$ and $25 \%$ and lost viability around $14 \%$ and $8 \%$ moisture content, respectively.

Both for B. salicifolius and C. decandra there was a slight increase in the germination speed index (GSI) in seeds with 33\% and $49 \%$ moisture content, and after $25 \%$ moisture there was a marked decrease in vigor (Figure 3). Thus, there is an increase in seed vigor at the beginning of the reduction of moisture.

Pupim et al. (2009) and Faria et al. (2004) also observed an increase in the physiologic potential of Magnolia ovata and Inga vera at the beginning of drying, and attributed this increase to the continued maturation during the drying period.

The results obtained in the tetrazolium test were consistent with the germination test. There was a decrease in viability starting at $29 \%$ moisture content for B. salicifolius, and for C. decandra there was a decrease in viability starting at $25 \%$ 
moisture content. Whereas with $14 \%$ and $8 \%$ seed moisture, respectively, the viability was zero (Figure 4).

\section{B. salicifolius}
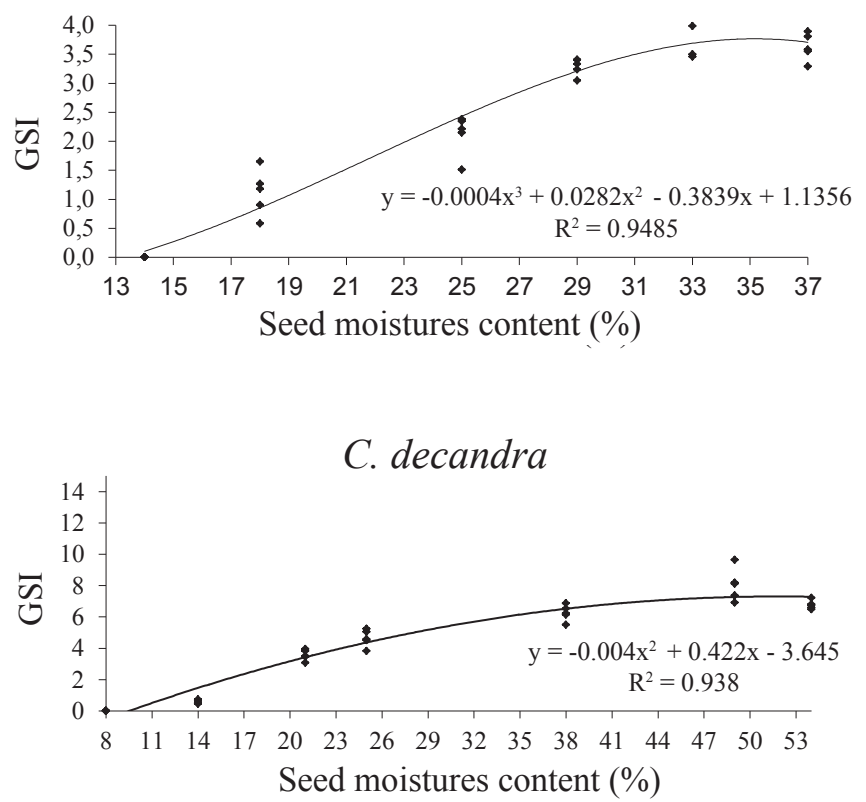

Figure 3. Germination speed index (GSI) of Blepharocalyx salicifolius and Casearia decandra with different moisture contents.

\section{B. salicifolius}

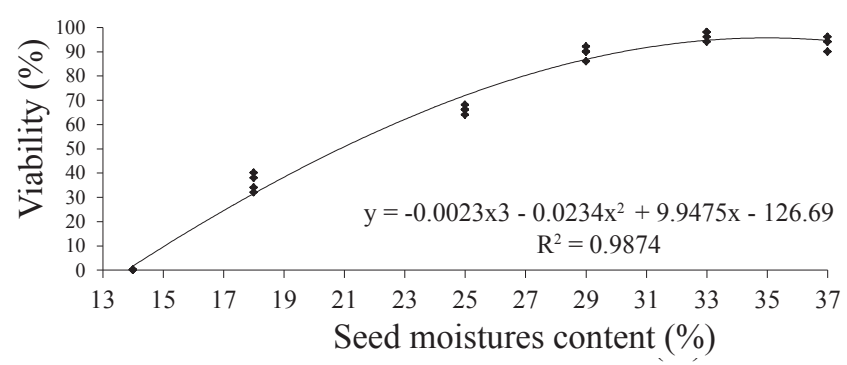

C. decandra

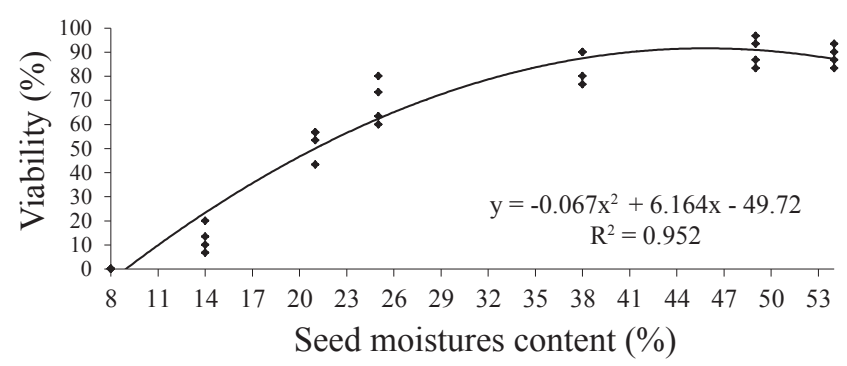

Figure 4. Viability by tetrazolium test of Bepharocalyx salicifolius and Casearia decandra seeds with different moisture contents.
In seeds of $B$. salicifolius and $C$. decandra the tetrazolium test was efficient to evaluate the viability of seeds subjected to dehydration, since according to the literature, there is a good correlation between seed viability and the activity of dehydrogenases, which are related to the respiratory activity of the seed (Popinigis, 1977).

Thus, it appears that, as the seeds lost moisture, breathing became less intense and consequently decreased the activity of dehydrogenases (Marcos-Filho, 2005). In Glycine max seeds, the tetrazolium test was also efficient in determining the viability, vigor, deterioration from moisture and damage due to drying (França-Neto, 1994).

From the results obtained in the germination and tetrazolium tests, it was found that the seeds of $B$. salicifolius and $C$. decandra do not tolerate drying below $29 \%$ and $25 \%$ moisture content, respectively, suggesting that these species may be classified as recalcitrant, because according to Roberts (1973), recalcitrant seeds are those that, as opposed to orthodox seeds, are very sensitive to desiccation, have a high degree of moisture when breaking off from the parent plant at the end of maturation, and die when their degree of moisture is reduced to values below their critical level of moisture (15 to $50 \%$ ). However, it should be noted that the level of desiccation tolerance may vary with the drying method, the year and the collection site and environmental conditions, making it necessary to perform further studies to evaluate the speed of drying and other sources.

Pammenter and Berjak (2000) also observed that recalcitrant seeds are usually produced by climax species and are not often found in the soil seed bank and do not present dormancy, germinating rapidly and persisting in the soil as a seedling bank. They are large and usually not dispersed by the wind. The species studied in this work have no dormancy and germinate quickly, being dispersed by animals, but do not apply to this rule for being small, and $C$. decandra is a secondary species (Klein and Sleumer, 1984).

Other features which are also associated with recalcitrant seeds and observed in the studied species are related to their morphology, such as the presence of a thin integument that does not restrict the loss of water.

The region of these species also predicts the physiological condition of the seeds. B. salicifolius and $C$. decandra occur in Tropical Forests, where rainfall is high, maintaining the high moisture content of the seeds. In this environment, the temperature, which is relatively high, favors the germination soon after the abscission from the parent plant.

Carvalho et al. (2006) observed a recalcitrant behavior for two species of Myrtaceae (Calyptranthes lucida and Eugenia handroana) and correlated this result with other specie 
belonging to the same family, who also have recalcitrant seeds, such as Myrciaria dubia (Gentil and Ferreira, 2000; Ferreira and Gentil, 2003). Thus, they observed that there is a tendency for the species of this family to exhibit a recalcitrant behavior. This information is important for studies of conservation of forest species, because from the knowledge of the family to which one determined species belongs, it will be possible to infer on the behavior of the seeds during the storage and to adopt correct procedures in the harvest, transportation and processing. However, care must be taken not to generalize, because species of the Eucalyptus genus belong to the Myrtaceae family and their seeds have orthodox behavior.
As for the Salicaceae family, there is no data in the literature on the physiological behavior of seeds. It should also be noted that there is great variability within the family and within the same genus, since Casearia sylvestrishas morphological characteristics quite different from $C$. decandra and according to Imatomi et al. (2009) it possibly has an orthodox behavior.

The electrical conductivity of $B$. salicifolius seeds with $37 \%$ moisture content (without dehydration) was of $30 \mu \mathrm{S} \cdot \mathrm{cm}^{-1} \cdot \mathrm{g}^{-1}$. From $33 \%$ moisture content, this value decreased to $\mu \mathrm{S} . \mathrm{cm}^{-1} \cdot \mathrm{g}^{-1}$ and at $25 \%$ moisture, it increased significantly to $35 \mu \mathrm{S} \cdot \mathrm{cm}^{-1} \cdot \mathrm{g}^{-1}$ (Figure 5).
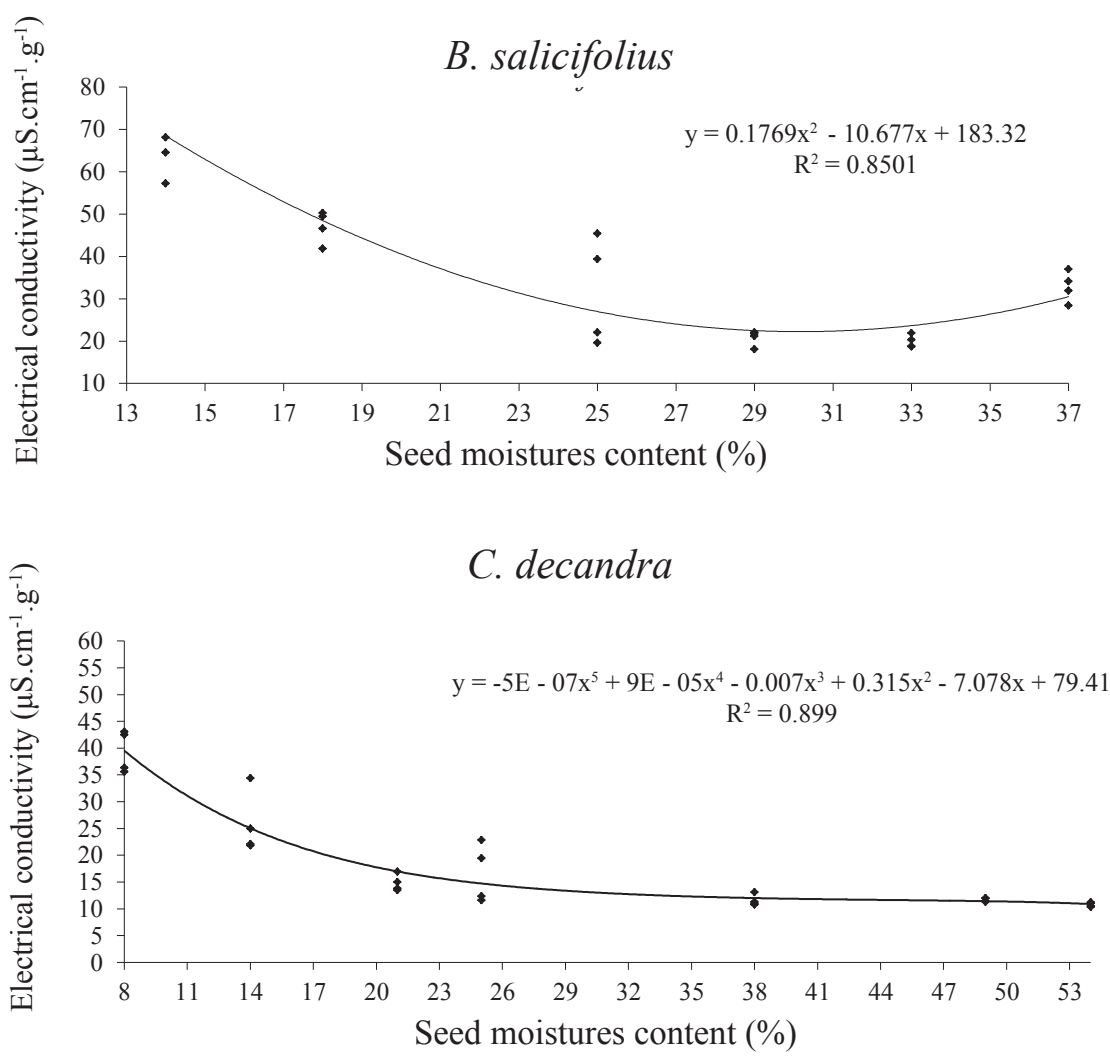

Figure 5. Electrical conductivity of Bepharocalyx salicifolius and Casearia decandra seeds with different moisture contents.

For seeds of $C$. decandra, the values of electrical conductivity remained at $13 \mu \mathrm{S} . \mathrm{cm}^{-1} \cdot \mathrm{g}^{-1}$ up to $38 \%$ moisture, and from $25 \%$ moisture content there was a significant increase to $20 \mu \mathrm{S} . \mathrm{cm}^{-1} \cdot \mathrm{g}^{-1}$ (Figure 5).

The dehydration of $B$. salicifolius and $C$. decandra seeds from $25 \%$ moisture content provided a large release of cellular solutes, due to changes in selective permeability of the plasma membrane, since according to AOSA (1983) the amount of leached solution is directly related to the integrity of cell membranes. Thus, it can be said that the loss of seed viability is strongly correlated with the gradual loss of integrity of the membrane system resulting in the release of cell solutes that are important for the functioning of the cell (Marcos-Filho, 2005).

Bilia et al. (1998) found an increased release of exudates by seeds of Inga uruguensis at $27 \%$ moisture content. In the seeds of $B$. salicifolius and $C$. decandra, similar results were obtained: an increase in electrical conductivity values starting at $25 \%$ moisture content.

These results are in agreement with Bewley and Black (1994), according to whom the membranes are disrupted when the seeds reach moisture content below $25 \%$, and values close to these can be considered critical for recalcitrant species. 
From the results obtained in the vigor and electrical conductivity tests, it was shown that seed vigor of $B$. salicifolius and $C$. decandra was affected starting at $25 \%$ moisture content.

\section{Conclusions}

Under of slow drying conditions, the seeds of $B$. salicifolius and $C$. decandra are sensitive to moisture reduction between $29 \%$ and $25 \%$ and lose viability around $14 \%$ and $8 \%$ moisture content, respectively.

As for the physiological changes during seed drying, there is a decrease in viability and vigor and an increase in electrical conductivity values starting at $25 \%$ moisture content.

$B$. salicifolius and C. decandra have several characteristics consistent with recalcitrant species and, in the conditions tested in this work, they exhibited behaviour non-tolerant to dehydration.

\section{References}

ABREU, D.C.A.; MEDEIROS, A.C.S. Comportamento fisiológico de sementes de branquilho (Sebastiana commersoniana), Euphorbiaceae em relação ao armazenamento. Informativo ABRATES, Pelotas, v.15, n.1- 3, p.291, 2005a.

ABREU, D.C.A.; MEDEIROS, A.C.S. Comportamento fisiológico de sementes de pixiricão (Miconia cabucu) em relação ao armazenamento. Informativo ABRATES, Pelotas, v.15, n.1- 3, p.291, 2005b.

ALPERT, P. The discovery scope and puzzle of desiccation tolerance in plants. Plant Ecology, v.151, p. 5-17, 2000.

ASSOCIATION OF OFFICIAL SEED ANALYSTS. AOSA. Seed vigor testing handbook. Lincoln: AOSA, 1983, 93 p. (Contribution, 32).

BERJAK, P.; PAMMENTER, N. What ultrastructure has told us about recalcitrant seeds? Revista Brasileira de Fisiologia Vegetal, v.12, p.22-55, 2000. http://www.cnpdia.embrapa.br/rbfv/v12ne.htmL

BEWLEY, J.; BLACK, M. Seeds: physiology of development and germination. New York: Plenum Press, 1994, 367p.

BILIA, D.A.C.; MARCOS- FILHO, J. NOVEMBRE, A.D.L.C. Conservação da qualidade fisiológica de sementes de Inga uruguensis. Revista Brasileira de Sementes, v.20, n.1, p.48- 54, 1998. http://www.abrates.org.br/revista/ artigos/1998/v20n1/artigo09.pdf

BRASIL. Ministério da Agricultura e Reforma Agrária. Regras para análise de sementes. Brasília: MAPA/ACS, p157-162, 2009. http://www.bs.cca.ufsc. $\mathrm{br} /$ publicacoes/regras $\% 20$ analise $\% 20$ sementes.pdf

CADDAH, M.K.; ANDRADE, B.O.; MEDEIROS, A.C.S. Efeitos da desidratação e do armazenamento em sementes de Talauma ovata St. Hil.Magnolizceae. Informativo ABRATES, v.15, n.1-3, p.285, 2005.

CARVALHO, P.E.R. Espécies arbóreas brasileiras. v.2. Colombo: Embrapa Florestas, 2006. p.380-386,
CARVALHO, L.R.; SILVA, E.A.A.; DAVIDE, A.C. Classificação de sementes florestais quanto ao comportamento no armazenamento. Revista Brasileira de Sementes, v.28, n.2, p.15-25, 2006. http://www.scielo.br/pdf/ rbs/v28n2/a03v28n2.pdf

DAWS, M. I.; GARWOOD, N.C.; PRITCHARD, H.W. Traits of recalcitrant seeds in a semi-deciduous tropical forest in Panamá: some ecological implications. Functional Ecology, v.19. p.874-885, 2005. http://si-pddr.si.edu/ jspui/bitstream/10088/3844/1/Daws_Garwood_and_Pritchard_2005.pdf

DELGADO, L.F.; BARBEDO, C.J. Tolerância à dessecação de sementes de espécies de Eugenia. Pesquisa Agropecuária Brasileira, v.42, p.265-272, 2007. http://www.scielo.br/pdf/pab/v42n2/16.pdf

DUSSERT, S.; CHABRILLANGE, N.; ENGELMANN, F.; ANTHONY, F.; LOUARN, J.; HAMON, S. Relationship between seed desiccation sensitivity, seed moisture content at maturity and climatic characteristics of native environments of nine Coffea L. species. Seed Science Research, v.10, p.293-300, 2000.

ELLIS, R.H.; HONG, T.D.; ROBERTS, E.H. An intermediate category of seed storage behaviour? I. Coffee. Journal of Experimental Botany, v.41, n. 230, p. 1167-1174, 1990.

FARIA, J.M.R.; VAN LAMMEREN, A.A.M.; HILHORST, H.W. M. Desiccation sensitivity and cell cycle aspects in seeds of Inga vera subsp. affinis. Seed Science Research, v.14, n.2, p. 165-178, 2004.

FARRANT, J.M.; PAMMENTER, N.W.; BERJAK, P. The increasing desiccation sensitivity of recalcitrant Avicennia marina seeds with storage time. Physiologia Plantarum, v. 67, p. 291-298, 1986.

FARRANT, J.M., PAMMENTER, N.W., BERJAK, P. Recalcitrance: a current assessment. Seed Science and Technology, v. 16, n.1, p. 155-166, 1988. http://210.72.92.31/bitstream/353005/3249/1/Seed\%20recalcitrance $\% 20$ $\% 20 \mathrm{a} \% 20$ current $\% 20$ assessment.pdf

FERREIRA, S.A.N.; GENTIL, D.F.O. Armazenamento de sementes de camu-camu (Myrciaria dubia) com diferentes graus de umidade e temperaturas. Revista Brasileira de Fruticultura, v.25, n.3, p.440-442, 2003. http://www.scielo.br/pdf/rbf/v25n3/18663.pdf

FRANÇA-NETO, J. B. O teste de tetrazólio em sementes de soja. In: VIEIRA, R.D., CARVALHO, N.M. Testes de vigor em sementes. Jaboticabal: FUNEP, 1994. p. 87-102.

GENTIL, D.F.O.; FERREIRA, S.A.N. Tolerância à dessecação e viabilidade de sementes de camu-camu. Revista Brasileira de Fruticultura, v.22, n.2, p. 264-267, 2000.

IAPAR. Cartas climáticas do Paraná. Disponível em $<\mathrm{http} / /$ www.iapar.br $>$. Accessed on: Jan. $21^{\text {st }} 2013$.

IMATOMI, M.; PEREZ, S.C.J.G.; FERREIRA, A.G. Caracterização e comportamento germinativo de sementes de Caesaria sylvestris Swartz (Salicaceae). Revista Brasileira de Sementes, v.31, n.2, p.36-47, 2009. http:// www.scielo.br/pdf/rbs/v31n2/v31n2a04.pdf

KLEIN, R.M.; SLEUMER, H.O. Flacourtiaceae. In: REITZ, P.R. Flora Ilustrada Catarinense, Itajaí: Herbário Barbosa Rodrigues, 1984. 95p.

LORENZI, H. Árvores Brasileiras: Manual de identificação e cultivo de plantas arbóreas nativas do Brasil. v.2. Nova Odessa: Plantarum, 1998. 352 p.

MAGUIRE, J.D. Speed of germination aid in selection and evaluation for seedling emergence and vigor. Crop Science, v.2, n.1, p. 176-177, 1962.

MARCHIORI, J.N.C.; SOBRAL, M. Dendrologia das Angiospermas: Myrtales. Santa Maria: Editora da UFSM, 1997. 304p. 
MARCOS-FILHO, J. Fisiologia de sementes de plantas cultivadas. Piracicaba: FEALQ, 2005.495p.

MEDEIROS, A.C.S. Preparo e uso de soluções salinas saturadas para a caracterização fisiológica de sementes florestais. Circular Técnica, 125. Colombo: Embrapa Florestas, 2006, 5p. http://www.cnpf.embrapa.br/ publica/circtec/edicoes/circ-tec125.pdf

MERCK. The Merck Index: an encyclopedia of chemicals, drugs, and biologicals. 11.ed. New York: Merck, 1989. 1605p.

PAMMENTER, N. W.; BERJAK, P.; WALTERS, C. The effect of drying rate on recalcitrant seeds: "lethal moisture contents", causes of damage, and quantification of recalcitrance. In: BLACK, M.; BRADFORD, K. J.; VAZQUEZ-RAMOS, J. (Ed.). Seed biology: advances and applications. Wallingford: CABI Publishing, 2000. p. 215-221.

PAMMENTER, N.W.; BERJAK, P. Aspects of recalcitrant seed physiology. Revista Brasileira de Fisiologia Vegetal, v.12, p.56-69, 2000. http://www. cnpdia.embrapa.br/rbfv/v12ne.htmL

PIO CORRÊA, M. Dicionário das plantas úteis do Brasil e das exóticas cultivadas. v.2. Rio de Janeiro: Instituto de Desenvolvimento Florestal, 1984. 687p.

POPINIGIS, F. Fisiologia da semente. Brasília: AGIPLAN, 1977. 289p.

PUPIM, T.L, NOVEMBRE, A.D.L., BRANCALION, P.H.S., MORAES, M.H.D., MONDO, V.H.V.; LABONIA, V.D. S. Conservação de sementes de Magnolia ovata St. Hil. Revista Brasileira de Sementes, v.31, n.3, p.96-105, 2009. http://www.scielo.br/pdf/rbs/v31n3/a11v31n3.pdf

REGO, S.S.; NOGUEIRA, A.C.; KUNIYOSHI, Y.S.; SANTOS, Á.F. Germinação de sementes de Blepharocalyx salicifolius (H.B.K.) Berg. em diferentes substratos e condições de temperaturas, luz e umidade. Revista Brasileira de Sementes, v. 31, n. 2, p. 212-220, 2009. http://www.scielo.br/ $\mathrm{pdf} / \mathrm{rbs} / \mathrm{v} 31 \mathrm{n} 2 / \mathrm{v} 31 \mathrm{n} 2 \mathrm{a} 25 . \mathrm{pdf}$
REGO, S.S.; NOGUEIRA, A.C.; KUNIYOSHI, Y.S.; SANTOS, A.F. Caracterização morfológica do fruto, da semente e do desenvolvimento da plântula de Blepharocalyx salicifolius (H.B.K.) Berg. e Myrceugenia gertii Landrum - Myrtaceae. Revista Brasileira de Sementes, v. 32, n.3, p. 52-60, 2010. http://www.scielo.br/pdf/rbs/v32n3/v32n3a06.pdf

ROBERTS, E.H. Predicting the storage life of seeds. Seed Science and Technology, v. 1, p. 499-514, 1973.

ROCKLAND, L.B. Saturaded salt solutions for static control of relative moisture between $5^{\circ} \mathrm{C}$ and $40^{\circ} \mathrm{C}$. Analytical Chemistry, v.32, n.10, p.1375-1376, 1960.

SUN, W.Q. Methods for the study of water relations under desiccation stress. In: BLACK, M.; PRITCHARD, H.W. Desiccation and survival in plants: drying without dying. New York: CABI Publishing, 2002. p.47-91

SUN, W.Q.; LIANG, Y. Discrete levels of desiccation sensitivity in various seeds as determined by the equilibrium dehydration method. Seed Science Research, v.11, p.317-323, 2001.

THADEO, M.; MEIRA, R.M.S.A., AZEVEDO, A.A., VIEIRA, J.M.A. Anatomia e histoquímica das estruturas secretoras da folha de Casearia decandra Jacq. (Salicaceae). Revista Brasileira de Botânica, v.32, n.2, p.329338, 2009. http://www.scielo.br/pdf/rbb/v32n2/a12v32n2.pdf

VERTUCCI, C.W.; ROOS, E.E. Theoretical basis of protocols for seed storage II. The influence of temperature on optimal moisture levels. Seed Science Research, v.3, n.3, p.201-213. 1993.

WINSTON, P.W.; BATES, D.H. Saturated solutions for the control of moisture in biological research. Ecology, v.41, n.1, p. 232-237. 1960. 